\title{
Mind and Language
}

Wolfson College Lectures 1974

\section{Edited by Samuel Guttenplan}

The abilities to think and to use language are not independent of one another, and an acceptable account of the nature of this interdependency must be primarily philosophical. The issues surrounding this question are among the most important and characteristic of philosophy today, and these essays - by G. E. M. Anscombe, Donald Davidson, Michael Dummett, D. Føllesdale, P. T. Geach, and W. V. Quine - provide a useful starting point for its solution. $\mathfrak{£ 4 . 2 5}$

\section{Truth and Meaning}

Essays in Semantics

\section{Edited by Gareth Evans and John McDowell}

Most of the papers in this volume bear upon the general question 'What is the nature of an acceptable theory of meaning?', taking as their starting point an answer proposed by Donald Davidson. The contributors are Donald Davidson, Michael Dummett, J. A. Foster, Saul Kripke B. Loar, C. A. B. Peacocke, P. F. Strawson, B. Taylor, D. Wiggins, M. J. Woods and C. J. G. Wright. $£ 9.50$

\section{Problems from Locke}

\section{J. L. Mackie}

There is a growing tendency for philosophers to pay closer attention to John Locke's work, and as a result to treat it with greater respect. This book will support and encourage this tendency. It takes up several topics including perception, substance and essence, abstract ideas and universals, personal identity, and empiricism and innate notions. $£ 6$ paper covers $£ 2.50$

\section{Hume's Moral Epistemology}

J. Harrison

This book is a critical examination of Book III, Part I of $A$ Treatise of Human Nature, together with the relevant parts of An Enquiry Concerning the Principles of Morals, in which David Hume tries to answer the question 'How do we know the difference between right and wrong, good and bad, virtue and vice?'. The author unravels and assesses Hume's arguments against ethical racialism, and the different strands in his positive views, in the light of subsequent advances made in moral epistemology. $£ 4.25$ paper covers $£ 1.95$

\section{Oxford University Press}




\section{Existentialism and Sociology}

A Study of Jean-Paul Sartre

\section{IAN CRAIB}

A study of the work of Jean-Paul Sartre and of its relevance for contemporary sociology. In the first part of the book Dr Craib concentrates on Being and Nothingness; in the second part he examines La Critique de la raison dialectique.

$\$ 6.95$ net

CAMBRIDGE STUDIES IN THE HISTORY AND THEORY OF POLITICS

\section{Freedom and Independence}

A Study of the Political Ideas of Hegel's Phenomenology of Mind

\section{JUDITH SHKLAR}

This book has been written for students who want to understand and appreciate Hegel's political ideas as they appear in his first major philosophical work, The Phenomenology of Mind. Professor Shklar has written her commentary in simple, plain language, using English translations of references wherever possible.

\&5.95 net

\section{Dilthey}

\section{Selected Writings}

Edited, translated and introduced by H. P. RICKMAN

Dilthey is a figure of real importance in modern European philosophy and social theory. Dr Rickman has translated a substantial selection from the great corpus of Dilthey's output, and provided a long introduction to give the reader the background he needs to assess Dilthey's work as a whole.

\section{Morality}

£8.75 net

An Introduction to Ethics

BERNARD WILLIAMS

'Williams' book is brief but excellent; a clear, vigorous and fertile introduction to ethics.'

Philosophy

Hard covers $\$ 3.95$ net

Paperback edition

Paperback $\$ 1.25$ net

\section{Problems of the Self}

Philosophical Papers 1956-1972

\section{BERNARD WILLIAMS}

$\therefore$. to read only a few pages of it is to get a fine impression of the character, or flavour, of contemporary philosophy.'

The Listener Paperback £2.95 net

\section{CAMBRIDGE UNIVERSITY PRESS}




\section{Must We Mean What We Say? STANLEY CAVELL}

A remarkable, and now famous, volume of philosophical studies. The essays span and connect topics in the philosophy of language, aesthetics, and the criticism of literature, drama and music. The book is a distinguished personal work, of permanent interest and value.

Hard covers $£ 7.50$ net

Paperback $£ 2.75$ net

\section{What is Truth?}

\section{J. F. WILLIAMS}

A study in philosophical logic of the meaning of 'true'. Dr Williams demonstrates the shortcomings of various analyses which interpret truth as a property or as a relation, and clears up a number of important points about propositions, quantification, definite descriptions, and correspondence. This 'deflationary metaphysics' is interwoven with a positive theory of his own which seeks to develop ideas of the late Arthur Prior.

$£ 4.90$ net

\section{Linguistic Behaviour JONATHAN BENNETT}

Jonathan Bennett presents a view of language as essentially a matter of systematic, communicative behaviour. He offers an account of meaning in terms of the communicative intentions of speakers, and tries to show how these intentions can be known from behaviour other than the use of language itself. This theory of language is related to rival and related approaches and in particular to the work of Grice, Ziff, Davidson, Quine, Lewis and Chomsky.

£6.95 net

Paperback edition

\section{Logic of Statistical Inference} IAN HACKING

'For the first time we have in one book a review of all the main compering ideas of statistical inference, with a discussion of their philosophical implications.'

Journal of the Royal Statistical Society

Paperback $\$ 2.95$ net

\section{CAMBRIDGE UNIVERSITY PRESS}




\section{a short history of}

\section{WESTERN PHILOSOPHY Johannes Hirschberger}

Now at last this helpful compendium is available in the English language. Since its appearance on the continent fifteen years ago it has been reprinted almost every year, affording a useful account for student and layman alike of the most important names and concepts down through the ages.

Hirschberger provides a survey stretching from the philosophy of antiquity to the present century, thus dealing with those who laid the foundations of many current trends in modern philosophy.

Two new titles in the Library of

Philosophy and Religion

General Editor: John Hick AN INTRODUCTION TO THE PHILOSOPHY OF BERNARD LONERGAN

\section{Hugo A. Meynell}

". . Lonergan's philosophy is one of the outstanding achievements of our time, and applicable to a vast range of pressing intellectual, moral, social, political, educational and religious problems. Its neglect up to the present seems to me both astonishing and deplorable. Practitioners of the relevant fields of enquiry on the whole do not attempt either to use or refute Lonergan's arguments, but take the simpler course of failing to advert to their existence. If this introduction does anything at all to reverse the situation, it will have achieved its purpose' - from the author's conclusion.

$$
£ 10.00
$$

\section{THE RELEVANCE OF NATURAL SCIENCE TO THEOLOGY}

\section{William H. Austin}

The thesis that religion and science are mutually exclusive realms of thought has a large following among scientists and theologians today. William Austin is explicitly concerned with the question of the bearing of science on theology, not theology on science, and examines in some detail the main types of argument and what if anything they can be seen to prove. $£ 7.95$

For further details please write to Anne Calcott (Phil), The Macmillan Press, Little Essex Street, London WC2R 3LF.

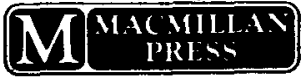




\section{The Monist}

An International Quarterly Journal

of General Philosophical Enquiry

Founded 1888 by Edward C. Hegeler

Editor, Eugene FREEMAN

Editorial Board: William P. Alston, Monroe C. Beardsley, Lewis White Beck, William A. Earle, Dagfinn Føllesdal, William Frankena, Maurice Mandelbaum, R. Barcan Marcus, Richard Martin, Mary Mothersill, Joseph Owens, Richard Rorty, J. B. Schneewind, Wilfrid Sellars, John E. Smith, Richard Wasserstrom.

Managing Editor: Ann FREEMAN

EACH ISSUE IS LIMITED TO ARTICLES ON A SINGLE GENERAL TOPIC. Communicate with the Editor in advance for Special Instructions. Papers should be 4000-8000 words in length and must be submitted in duplicate nine months prior to the scheduled publication of the issue, accompanied by return postage.

\section{SCHEDULED PUBLICATION DATES:}

Vol. 60, No. 1 Jan., 1977 Bioethics and Social Responsibility

Vol. 60, No. 2 Apr., 1977 Philosophy and Religion in the Nineteenth Century

Vol. 60, No. 3 July, 1977 New Directions in Semantics

Vol. 60, No. 4 Oct., 1977 Historicism and Epistemology

Vol. 61, No. 1 Jan., 1978 Conceptions of the Self: East and West

Vol. 61, No. 2 Apr., 1978 The Philosophy of Thomas Reid

Vol. 61, No. 3 July, 1978 Nominalism, Past and Present

Vol. 61, No. 4 Oct., 1978 The Philosophy and Psychology of Cognition

Editorial Office: Box 1908, Los Gatos, California 95030 Business Office: Box 600, La Salle (Illinois 61301)

SUBSCRIPTION RATES: United States: Annual (4 issues): Institutions, \$18.00; individuals, $\$ 12.00$. Single copies: $\$ 4.50$. Foreign postage: add 25 cents to single copy rate or $\$ 1.00$ to subscription rate.

Oxford Journals

\section{The British Journal of Aesthetics}

\section{Volume 16 No. 2 Spring 1976}

\section{Contents}

The New Sensibility of the 1960s Harold Osborne

Some Words Used in Appraising Works of Art E. J. Bond

Why Should We Take Art Seriously? Phillip Meeson

The Impossibility of a Uniquely Authentic

Marxist Aesthetics James P. Scanlan

Ruskin's 'Massy Commonsense' M. Hardman

The Vacuity of Musical Expressionism M. P. T. Leahy

Logics as Models of Music Peter Gibbins

The Slow Radical: Restrictions on the Artist

as Change Agent Arnold W. Foster

Book Reviews

The British Society of Aesthetics: Colloquia

To place an order or obtain an inspection copy please write to: Journals Manager, Oxford University Press, Press Road, Neasden, London NW10 0DD. 


\section{AMERICAN PHILOSOPHICAL QUARTERLY}

Edited by

Volume 13 Number 3

\section{NICHOLAS RESCHER}

Contents

RoBert CoBURn: The Persistence of Bodies

George Schlesinger: An Important Necessary Difference between People and Mindless Machines

Ronald Suter: The Dream Argument

Frederick MichaEL: What is the Master Argument of Diodorus Cronus?

ANNETTE BAIER: Mixing Memory and Desire

I. T. OAKLEY: An Argument for Scepticism concerning Justified Belief

STEPHEN R. SCHIFFER: A Paradox of Desire

Annual Subscription: $\mathbf{\$ 2 8}$ to Institutions, $\mathbf{\$ 1 2}$ to Individuals

Published by BASIL BLACKWELL, Oxford

Orders to: 108 Cowley Road, Oxford OX4 1JF, England

Vol. LXXXIV No. 335

\section{MIND}

\section{Edited by D. W. HAMLYN}

Articles:

The Primacy of Promising: M. H. Robins

Feeling of Obligation: W. NEBLETT

Reduction and Secondary Qualities: R. E. TuLtY

Art and Generality: D. Pole

Concepts of Consciousness in Aristotle: W. F. R. HARDIE

Discussions:

Awareness of Sensory Experience: J. B. MAUnd

The Perfect Island: W. E. MANN

A Note on the Frege Argument C. McGinN

Could Body-bound Immortality be Livable?: H. STEELE

On Benevolence: A. Koursouvilis

Distribution and Suppositio: P. T. GeaCH

Critical Note:

Frege: Philosophy of Language by Michael Dummett: P. T. GEACH

Book Reviews

Notice

Published for the MIND ASSOCIATION by BASIL BLACKWELL

Single Issues: $£ 1.25$

Annual Subscription: $£ 4.00$ 


\section{THE PHILOSOPHICAL QUARTERLY}

CONTENTS OF VOLUME 26, No. 103

APRIL 1976

Articles

The Argument of Republic IV

Leibniz on Compossibility and Relational Predicates

J. R. S. Wilson

"Inexplicable Knowledge" Does not Require Belief

F. B. D'Agostino

D. S. Mannison

Discussions

Moral Rules

Russell on Existence and Descriptions

R. G. Frey

On Seeing the Truth: A Reply

D. A. Griffiths

R. Almeder

Book Reviews

Books Received

Edited in the University of St Andrews by Bernard Mayo with the assistance of Christopher Bryant, Anthony Ellis and Stephen Read

Published for the Scots Philosophical Club by the University of St Andrews

Annual Subscriptions

Individuals $£ 3.00$ (\$8.50)

Institutions $£ 5.00(\$ 14.00)$

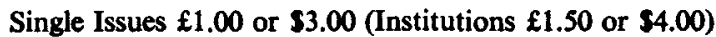

for orders placed directly with the Journals Manager, Scottish Academic Press Ltd., 33 Montgomery St., Edinburgh EH7 5JX, Scotland. 
Issues in the Philosophy of

\section{Language}

\section{Proceedings of the 1972 Oberlin \\ Colloquium in Philosophy}

Alfred F. MacKay and Daniel D. Merrill, editors

The papers and commentaries collected here are a productive and informative contribution to contemporary philosophy. Major contributors are Alan Ross Anderson, Fred Sommers, David Shwayder, Robert Stalnaker, Charles Landesman, and Zeno Vendler; with Lawrence Powers, Jay Rosenberg, and Charles Caton serving as commentators. \$I 2.50

\section{Hegel's Dialectic}

\section{Five Hermeneutical Studies}

\section{Hans-Georg Gadamer}

Translated and with an introduction by P. Christopher Smith

These five essays on Hegel give the

English-speaking reader a long-awaited opportunity to read the work of one of Germany's most distinguished philosophers, Hans-Georg Gadamer. Gadamer's unique hermeneutic method will have a lasting effect on Hegel studies. \$10.00

\section{Psychiatry and the Humanities}

\section{Volume I}

Joseph Smith, M.D., editor

The first in a series of volumes applying the insights and methodologies of psychoanalysis to the humanities. In this book, six humanists and five psychoanalysts cover a wide range of topics including art. literature, philosophy, language, mysticism, ethics, truth, healing, and creativity. \$I 2.50

\section{A New Language for Psychoanalysis}

Roy Schafer

A provocative and brilliant book offering a radical reconceptualization of Freudian metapsychology. Schafer proposes a new language for psychoanalysis, freed from the ambiguities and biases of mechanistic theory. He presents a philosophically oriented view of the person as agent, one who does things for reasons and creates his or her own experiences. $\$ \mathbf{2 0 . 0 0}$

\section{Essential Works of Socialism}

Irving Howe, editor

The authoritative one-volume anthology of major socialist writings, is now once more available. Offering a historical perspective of democratic socialism from Marx to contemporary writers, it is the essential resource for understanding socialist thought. $\quad$ c. $\$ 20.00 \quad$ p. $\$ 8.95$

\section{Now available in paperback \\ The Practice of Death}

\section{Eike-Henner W. Kluge}

"There are six chapters in the book: abortion, suicide, euthanasia, infanticide, senicide, and morality and the practice of death. ... The purpose of the book is to examine critically the representative positions held in society about the matters of life and death in each of the issues covered. ... This book serves as a philosophical survey of the practical ethical problems that trouble our society." - Review of Books and Religion c. \$ro.oo p. $\$ 3.95$

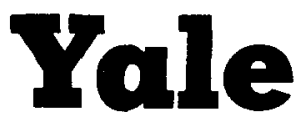

Yale University Press New Haven and London 